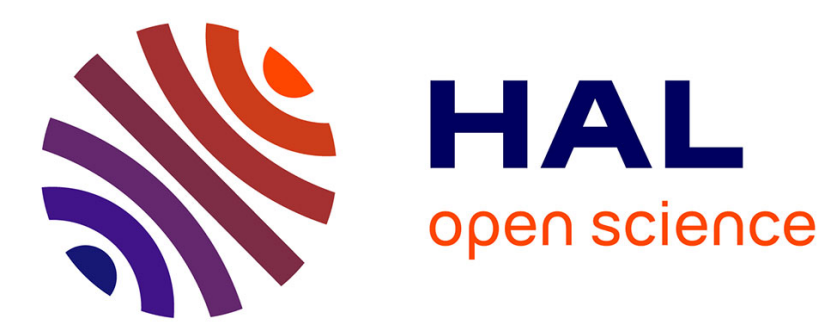

\title{
XAFS Characterization of Copper in Model Aqueous Systems of Humic Acid and Illite
}

\author{
D. Hesterberg, D. Sayers, W. Zhou, W. Robarge, G. Plummer
}

\section{To cite this version:}

D. Hesterberg, D. Sayers, W. Zhou, W. Robarge, G. Plummer. XAFS Characterization of Copper in Model Aqueous Systems of Humic Acid and Illite. Journal de Physique IV Proceedings, 1997, 7 (C2), pp.C2-833-C2-834. 10.1051/jp4:1997253 . jpa-00255332

\section{HAL Id: jpa-00255332 https://hal.science/jpa-00255332}

Submitted on 1 Jan 1997

HAL is a multi-disciplinary open access archive for the deposit and dissemination of scientific research documents, whether they are published or not. The documents may come from teaching and research institutions in France or abroad, or from public or private research centers.
L'archive ouverte pluridisciplinaire HAL, est destinée au dépôt et à la diffusion de documents scientifiques de niveau recherche, publiés ou non, émanant des établissements d'enseignement et de recherche français ou étrangers, des laboratoires publics ou privés. 


\title{
XAFS Characterization of Copper in Model Aqueous Systems of Humic Acid and Illite
}

\author{
D. Hesterberg, D.E. Sayers*, W. Zhou*, W.P. Robarge and G.M. Plummer* \\ Department of Soil Science, Box 7619, North Carolina State University, Raleigh NC 27695, U.S.A. \\ * Department of Physics, Box 7518, North Carolina State University, Raleigh NC 27695, U.S.A.
}

\begin{abstract}
Adsorption of heavy metals at mineral surfaces and complexation with reactive organic-matter functional groups are important processes regulating the solubility and fate of soil contaminants. To determine the nature of $\mathrm{Cu}(\mathrm{II})$ bonding in complex clay-organic systems, XAFS analyses were conducted on aqueous suspensions containing $\mathrm{Cu}$ (II) in various forms: (i) complexed with soil humic acid (HA) at various HA:Cu ratios, (ii) bound to illite, or (iii) bound in a mixture of illite and HA. Spectral features for $\mathrm{Cu}$ bound to HA did not depend significantly on the HA:Cu ratio, and average first-shell $\mathrm{Cu}-\mathrm{O}$ bond lengths were consistently shorter than for the $\mathrm{Cu}$-illite systems. In the mixed clay-organic suspension, $\mathrm{Cu}$ bonding was more characteristic to that of $\mathrm{Cu}$ bound with $\mathrm{HA}$.
\end{abstract}

\section{INTRODUCTION}

Soils and other complex matrices of environmental significance contain mixtures of minerals and organic matter that bind heavy metals. Although XAFS has revealed much about the molecular-scale nature of metal binding to mineral surfaces [1], its application to structurally more heterogeneous organic matter, clay-organic mixtures, and soils has been limited [2]. Using XAFS spectroscopy to characterize adsorbed heavy metals in heterogeneous systems such as soils is complicated by a preponderance of oxygen in the first coordination shell and often weak $\mathrm{x}$-ray backscatterers $(\mathrm{Si}, \mathrm{Al}, \mathrm{C}$, and $\mathrm{H}$ ) in higher shells. The objective of this study was to determine spectroscopic features that distinguish $\mathrm{Cu}(\mathrm{II})$ bonding to soil humic acid (HA) from bonding on an aluminosilicate mineral surface, and to characterize bonding in a mixed clay-organic system.

\section{MATERIALS AND METHODS}

The HA used in this study was extracted [3] from a Portsmouth surface soil sample (fine-loamy over sandy or sandy-skeletal, mixed, thermic Typic Umbraquults), HF washed to reduce its ash content [4], then fractionated using a nonionic (XAD8) exchange resin [5]. The HA contained no detectable sulfur. Silver Hill illite from the Source Clays Repository of the Clay Minerals Society was acid-washed and prepared as a stock suspension of $<1-\mu \mathrm{m}$ particle size. Samples at pH 5.6 or 7.3 were prepared in $\mathrm{NaClO}_{4}$ background solutions containing between 5 and $10 \mathrm{mM} \mathrm{Na}$. Suspensions initially containing $2.5 \mathrm{mmol}$ $\mathrm{Cu}(\mathrm{II}) / \mathrm{kg}$ and $\mathrm{HA}$ at concentrations ranging from 300 to $2400 \mathrm{mg}$ organic carbon (OC) per $\mathrm{kg}$ suspension at pH $5.6 \mathrm{were}$ equilibrated, gravity settled to concentrate the HA fraction, then analyzed. These concentrated samples contained between 5 and 9 mmol $\mathrm{Cu}(\mathrm{II}) / \mathrm{kg}$, with $<15 \%$ occurring as aqueous $\mathrm{Cu}$ in all but the two samples of lowest OC content. Suspensions containing $2.5 \mathrm{mmol} \mathrm{Cu}(\mathrm{II}) / \mathrm{kg}$ and (i) illite at a concentration of $26 \mathrm{~g} / \mathrm{kg}$, (ii) illite $(26 \mathrm{~g} / \mathrm{kg})+\mathrm{HA}(12.5 \mathrm{or} 25 \mathrm{mg} \mathrm{OC} / \mathrm{kg})$, or (iii) HA only (300 mg OC/kg - pH 7.3 sample) were analyzed while stirring in a tetrafluoroethylene sample holder. XAFS analyses were done at Beamline X-11A, National Synchrotron Light Source, Brookhaven National Laboratory. Samples were analyzed in fluorescence mode at the $\mathrm{Cu} \mathrm{K}$-edge $(8,979 \mathrm{eV})$ using a multielement detector. Dissolved $\mathrm{Cu}$-acetate was used as a standard representing aqueous $\mathrm{Cu}$ (II) octahedrally coordinated to oxygen. Fourier transforms were done on EXAFS spectra over the wavevector range $\mathrm{k}=2.3-11.5 \AA^{-1}$, and model fitting was done over the radial distance range $\mathrm{R}=0.9-1.9 \AA$.

\section{RESULTS AND DISCUSSION}

Figure 1 shows radial structure functions for $\mathrm{Cu}$ (II) in selected samples, and Table 1 contains EXAFS fitting results for all samples. The highest amplitude peak in Fig. 1 corresponds to first-shell $\mathrm{Cu}-\mathrm{O}$ bonding, and shows a detectable shift to higher radial distance between the HA, illite $+\mathrm{HA}$, and illite samples. The positions of weak, higher-shell peaks between 2 and $4 \AA$ for the mixed clay-organic suspension were more consistent with peaks for the HA suspension than for the illite suspension.

Table 1 shows that for both $\mathrm{pH}$ levels, the average first-shell $\mathrm{Cu}-\mathrm{O}$ bond lengths in the $\mathrm{HA}$ suspensions were consistently shorter than those of $\mathrm{Cu}-\mathrm{O}$ in the illite suspensions ( 1.92 to $1.93 \AA$ versus $1.95 \AA$, respectively). The average Cu-O bond length in the mixed illite-HA suspensions (1.94 $\AA$ ) was intermediate between those of the single adsorbent systems at pH 5.6 , and equal to that of $\mathrm{Cu}$ (II) in HA at pH $7.2(1.93 \AA$ ) (Table 1). Average coordination numbers (N) and Debye-Waller factors (DW) (bonding disorder) tended to be higher in the illite suspensions compared with the HA suspensions. Although $\mathrm{N}$ also tended to be higher in the mixed suspensions compared with HA alone, no consistent trend in DW was observed. In comparing the data for the HA suspensions at pH 5.6, there appeared to be little effect of HA:Cu ratio on EXAFS results (Table 1). 




Figure 1: Radial structure functions for $\mathrm{Cu}$ (II) in selected suspensions of humic acid (HA), illite, or mixed illite-HA at pH 5.6. Data are not corrected for phase shift; therefore, peaks do not represent exact bond lengths.

Table 1: First-shell EXAFS fitting results for $\mathrm{Cu}$ in humic acid (HA), illite, and mixed illite-HA suspensions using a $5 \mathrm{mM} \mathrm{Cu}$-acetate suspension as a standard $(\mathrm{N}=$ coordination number, $\mathrm{R}=1$ st-shell bond length, and $\mathrm{DW}=$ Debye-Waller factor). Numbers in parentheses are parameter standard deviations given as output from the University of Washington FEFF fitting program.

\begin{tabular}{lccc}
\multicolumn{1}{c}{ Sample } & $\mathrm{N}( \pm 0.5)$ & $\mathrm{R}(\AA)( \pm 0.01)$ & $\mathrm{DW}\left(\AA^{2}\right)( \pm 0.0004)$ \\
\hline Cu-acetate standard & 6.0 & 1.95 & 0.0000 \\
$\mathrm{HA}=300 \mathrm{mg} \mathrm{OC} / \mathrm{kg}, \mathrm{pH} 5.6$ & 5.4 & 1.93 & 0.0005 \\
$\mathrm{HA}=$ 600 mg OC/kg, pH 5.6 & 5.8 & 1.93 & 0.0008 \\
$\mathrm{HA}=1200 \mathrm{mg} \mathrm{OC} / \mathrm{kg}, \mathrm{pH} 5.6$ & 5.8 & 1.93 & 0.0009 \\
$\mathrm{HA}=1800 \mathrm{mg}$ OC/kg, pH 5.6 & 5.4 & 1.93 & 0.0005 \\
HA = 2400 mg OC/kg, pH 5.6 & 5.7 & 1.92 & 0.0005 \\
illite + HA - 12.5 mg OC/kg, pH 5.6 & 5.9 & 1.94 & -0.0004 \\
illite + HA - 25 mg OC/kg, pH 5.6 & 6.4 & 1.94 & 0.0010 \\
illite, pH 5.6 & 6.6 & 1.95 & 0.0010 \\
HA = 300 mg OC/kg, pH 7.3 & 6.5 & 1.93 & 0.0011 \\
illite + HA - 12.5 mg OC/kg, pH 7.3 & 6.5 & 1.93 & 0.0003 \\
illite, pH 7.3 & 6.9 & 1.95 & 0.0016 \\
\hline
\end{tabular}

Copper has a higher affinity for soil organic matter than many other heavy metals [6]. Also, the binding affinity of Cu(II) by the humic substance fulvic acid increases with increasing $\mathrm{pH}$ and decreasing $\mathrm{Cu} / \mathrm{OC}$ ratio [7]. The effect of $\mathrm{Cu} / \mathrm{OC}$ ratio has been attributed to preferential binding to high energy sites at low $\mathrm{Cu} / \mathrm{OC}$. Although we found that dissolved $\mathrm{Cu}$ decreased with decreasing $\mathrm{Cu} / \mathrm{OC}$ ratio at $\mathrm{pH} 5.6$ (data not shown), XAFS results for all of these samples were similar (Table 1). Our results did indicate that the addition of relatively low levels of HA to illite suspensions had a significant effect on average local bonding structure, and at pH 7.3, calculated bonding parameters for the mixed suspension were closer to those for HA than for illite.

\section{Acknowledgments}

The authors are grateful to Paul Hansen for assisting in preparing and analyzing samples. This work is supported by the US Department of Energy, Division of Materials Science under contract DE-FG05-89ER45384, and Beamline X-11 at the National Synchrotron Light Source, Brookhaven National Laboratory is supported by the US Department of Energy, Division of Materials Science under contract DE-AC02-76CH00016.

\section{References}

[1] Manceau, A., Charlet, L., Boisset, M. C., Didier, B., Spadini, L., Appl. Clay Sci. 7 (1992) 201-223.

[2] Manceau, A., Boisset, M. C., Sarret, G., Hazemann, J. L., Mench, M., Cambier, P., Prost, R., Environ. Sci. Technol. 30 (1996) $1540-1552$.

[3] Schnitzer, M., Schulten, H. R., Soil Sci. Soc. Am. J. 56 (1992) 1811-1817.

[4] Schnitzer, M., "Organic matter characterization", Methods of Soil Analysis - Part 2, 2nd ed., A. L. Page et al. Eds. (ASA-SSSA, Madison, WI, 1982) pp. 581-594.

[5] Malcolm, R. L., "Factors to be considered in the isolation and characterization of aquatic humic substances", Humic substances in the aquatic and terrestrial environment, H. Boren and B. Allard Eds. (Springer-Verlag, Berlin 1991) pp. 369-391.

[6] McBride, M. B., "Reactions controlling heavy metal solubility in soils", Adv. in Soil Sci., vol. 10, B. A. Stewart Ed., (SpringerVerlag, New York, 1989) pp. 1-56.

[7] Buffle, J., Complexation reactions in aquatic systems (Ellis Horwood Publishers, Chichester, 1988) pp. 304-383. 